\title{
The Influence of Delegation of Authority and Management Control on the Effectiveness of Managerial Decision-Making in the Arab Pharmaceutical Manufacturing Company Limited in Al-Salt City in Jordan
}

\author{
Mohammed A. Abu Rumman ${ }^{1} \&$ Amani Abdelhafeeth Alzeyadat ${ }^{2}$ \\ ${ }^{1}$ Department of Business Administration, Faculty of Business, Al- Balqa' Applied University, Jordan \\ ${ }^{2}$ Independent Scholar, Jordan \\ Correspondence: Dr. Mohammed A. Abu Rumman, Department of Business Administration, Faculty of Business, Al- \\ Balqa' Applied University, Jordan.
}

Received: April 28, 2019

doi:10.5430/ijba.v10n4p13
Accepted: May 13, 2019

Online Published: May 29, 2019

URL: https://doi.org/10.5430/ijba.v10n4p13

\begin{abstract}
The purpose of this study was to identify the influence of delegation of authority and administrative control on the effectiveness of managerial decisions in the Arab Pharmaceutical Manufacturing Company Limited in Al-Salt city in Jordan taking into account the demographic factors: gender, age, years of experience, educational qualifications, and job position. Data were collected through survey questionnaires, which were distributed among the sample of the study. The researchers used a census-style for collecting data from the population of the study which consisted of (286) employees in the Arab Pharmaceutical Manufacturing Company Limited in Al-Salt city. The (252) questionnaires that were distributed amongst the study sample were valid for statistical analysis. The researchers used many statistical methods, including; frequencies, percentages, arithmetic mean, standard deviation, simple and multiple regression. The results indicated that there was a statistically significant impact of the delegation of authority and administrative control on the effectiveness of management officials' administrative decisions of the Arab Pharmaceutical Manufacturing Company in Al-Salt city.
\end{abstract}

Keywords: delegation of authority, administrative control, effectiveness, managerial decisions, pharmaceutical, Jordan

\section{Introduction}

Delegating powers in business has arisen as a result of the increase of the functions and responsibilities carried out by management senior officials and decision makers in organizations and companies. Consequently, it has become difficult for managers and senior officials to perform all the functions and carry out all responsibilities on their own, even if they have a high level of expertise and efficiency. The delegation of authority gives senior managers the opportunity to deal with more serious business tasks including management decisions which help achieve the organization's desired goals (Darwish \& Al-Shammari, 2010). The researchers of the current study have focused on the issue of administrative control in companies since it helps senior managers to follow up on the progress of work delegated to subordinates. The purpose of this study was to identify the influence of delegation of authority and management control on the effectiveness of management officials' administrative decisions of the Arab Pharmaceutical Manufacturing Company Limited in Al-Salt city in Jordan.

\subsection{Problem of the Study}

The manifestations of the concentration of power in the hands of a limited number of senior managers leads to the occurrence of bottlenecks in business management and disrupts the interests of the beneficiaries of the activities of organizations or companies and negatively affects the morale of subordinates. As a result of this control of power by senior managers and the lack of delegation of authority to qualified subordinates, the organization's problems accumulate and the pace of work becomes stagnant due to the failure to address the problems in a timely manner. In fact, the problem of the concentration of power in the hands of a small number of senior managers and officials is one of the main problems in the Arab World. The problem lies in the difficulty and the risk subordinates face in taking 
decisions without obtaining the approval of their immediate supervisors and senior managers. This intimidation forces them to refrain from taking any decision and leaving all decisions even those related to trivial issues to senior decision makers. Such subordinates are reluctant to violate company policies pertaining to taking a decision without obtaining official approval from their supervisors and mangers (Othman, 2003).

The researchers have observed the phenomenon of the control of power by the Senior Manager or the organization's Director in several companies in Jordan. It should be made clear that management decision-making is one of the most important elements of the administrative process and is considered the most important indicators of an organization's success and failure. The study tries to answer the following questions whose answers constitute the theoretical and practical framework for organizations' decision makers:

1. What is the effect the delegation of authority on the effectiveness of administrative decision-making process in the Arab Pharmaceutical Manufacturing Company Limited in Al-Salt City- Jordan?

2. What is the impact of management control on the effectiveness of management decision-making the Arab Pharmaceutical Manufacturing Company Limited in Al-Salt City- Jordan?

3. Are there any statistically significant differences in the impact of the delegation of authority and management decision-making in the Arab Pharmaceutical Manufacturing Company Limited in Al-Salt City- Jordan attributed to demographic factors such as the manger's gender, age, job title, and educational qualification?

\subsection{Significance of the Study}

The importance of this study is that it discusses the important and vital subject of delegation of authority and its impact on the decision-making process in companies and organizations. This topic constitutes the cornerstone of the organizational structure of companies. Delegation of powers is important in the following respects:

1. Delegation of powers helps take the pressure off the shoulders of senior managers and gives them enough time to dedicate themselves to the core functions of leadership such as planning, supervision, and coordination. While leaving subordinate employees to perform ordinary tasks. Delegating powers to subordinates gives enough time to senior managers to deal with vital issues such as the follow-up and coordination between employees working in field, and in this way subordinates form a clear vision when making decisions and they in turn help train their associates on how to take right decisions independently (Diab, 2004).

2. Delegation of authority is a necessity for good administrative organization because it helps achieve the objectives assigned to each employee in the organization accomplish the tasks entrusted to him/her quickly and efficiently in addition to reducing the financial burden as a result of effectively delegating powers to creative subordinates (Altwaijri, 2006).

3. By virtue of their contact with beneficiaries of the organization, subordinates are more familiar with their needs and they have the data and facts that will enable them to make the right decisions concerning the services the organization offers to them. Thus, when delegated powers subordinate employees are more effective and more responsive than senior managers to the needs and aspirations of these beneficiaries (Alhelou, 2010).

4. The concentration of power in the hands of an individual or several individuals creates an atmosphere autocracy which disrupts the development of creativity amongst subordinates, leads to their passivity and indifference and increases the dominant authoritarian power in the workplace. Therefore, delegation of powers contributes to enhancing coordination in the workplace whereby collective efforts help do business quickly and efficiently

(Muhanna 2006).

\subsection{Objectives of the Study}

This study aims to identify the influence of delegation of authority and administrative control on the effectiveness of managerial decision-making in the Arab Pharmaceutical Manufacturing Company Limited in Al-Salt city in Jordan.

The objectives of the study can be summed up as follows:

1. Realizing the benefits of delegation of powers in the managerial decision-making in the Arab Pharmaceutical Manufacturing Company in Al-Salt City in Jordan.

2. Identifying the factors that hinder the delegation of powers to subordinate employees in the Arab Pharmaceutical Manufacturing Company in Al-Salt- Jordan.

3. Identifying the success factors of the delegation of powers in the Arab Pharmaceutical Manufacturing Company in Al-Salt City in Jordan. 
4. Identifying the influence of delegation of authority and administrative control on the effectiveness of managerial decision-making in the Arab Pharmaceutical Manufacturing Company Limited in Al-Salt city in Jordan in light of the demographic variables: gender, age, job position, educational qualifications, and years of experience.

5. Suggesting several recommendations for the management of Arab Pharmaceutical Manufacturing Company in Al-Salt City, which aim to increase the effectiveness of decision-making in the company.

\subsection{Research Chart}

As shown in figure (1) the research chart includes a dependent variable: the effectiveness of managerial decision-making of the Arab Pharmaceutical Manufacturing Company- Al-Salt City -Jordan, and the independent variables: the delegation of authority and management control, and the modified variables: demographics of employees (gender, age, job title, educational qualifications, and the number of years of experience).

\section{Dependent Variables}

\section{Independent Variables}

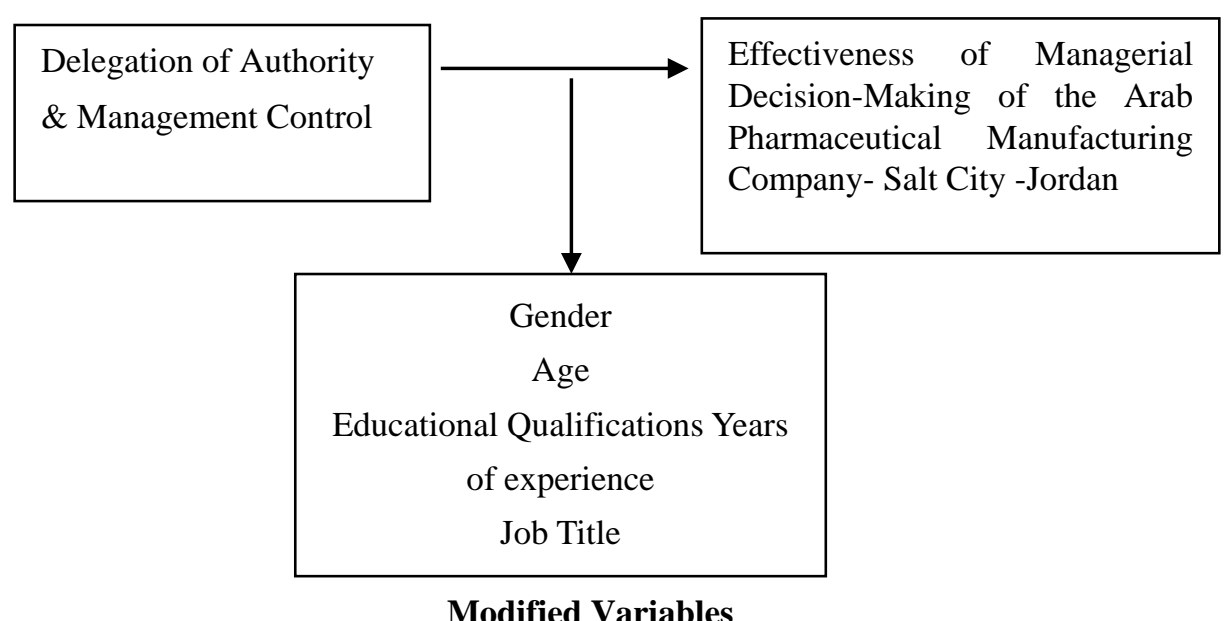

Figure 1. Research chart

Source: Prepared by the researchers with the useful help from other sources (Ababneh and Al- Jama'an, 2010) \& (Alfara, 2009)

\subsection{Study Hypotheses}

Based on the above discussion, the following hypotheses have been formulated:

First hypothesis: There is no statistically significant impact at the level $a \leq 0.05$ of delegating powers on the effectiveness of managerial decision-making in the Arab Pharmaceutical Manufacturing Company Limited in Al-Salt City in Jordan.

Second hypothesis: There is no statistically significant impact at the level $a \leq 0.05$ of management control on the effectiveness of managerial decision-making in the Arab Pharmaceutical Manufacturing Company Limited in Al-Salt City in Jordan.

Third hypothesis: There were no statistically significant differences at the level $a \leq 0.05$ in the impact of delegating powers and management control on the effectiveness of managerial decision-making in the Arab Pharmaceutical Manufacturing Company Limited in Al-Salt City in Jordan attributable to demographic factors (gender, age, job title, educational qualifications, and years of experience).

Fourth hypothesis: There were no statistically significant differences at the level $a \leq 0.05$ in the impact of management control on the effectiveness of managerial decision-making in the Arab Pharmaceutical Manufacturing Company Limited in Al-Salt City in Jordan attributable to demographic factors (gender, age, job title, educational qualifications, and years of experience). 


\section{Theoretical Framework}

\subsection{Review of Related Literature}

Vikrant and Serge (2019) conducted a study entitled "Organizational Controls and Performance Outcomes: A Meta Analytic Assessment and Extension". This study synthesizes the research on the effectiveness of organizational controls. The study examines 23,839 organizational controls-performance relationships from 120 independent samples, and tests several new hypotheses using advanced meta - analytic methods. The results indicate that outcome, behavior, and clan controls generally enhance performance, with each control having a distinct performance effect. The analysis also demonstrates that controls function as complements to one another. This finding indicates that one form of control increases the effectiveness of other forms of control.

El-Zubair and AL-Muqati (2018) conducted a study entitled: "Investigating the Extent of Schools Administrators practice to the Process of Authority Powers (Mandates) to their Deputies from the Standpoint of Deputies in Middle and Secondary Schools in the Province at AL-Taif" The aim of this study was to identify the extent to which school principals exercised authority to their agents from the point of view of agents in middle and secondary schools in AL-Taif. The researchers followed the descriptive approach. The study included 354 agents. The researchers chose a simple random sample of 120 agents. To many of the most important results: the practice of school principals to delegate powers to their agents came very high. And the practice of school principals to delegate their powers to their agents in planning, organization, technical supervision and evaluation came to a high degree.

Andrei and Johanna (2017) conducted a study entitled:" Delegation of Responsibilities and Decision Making Authority in Low Trust Countries". This paper aimed to study delegation in a low trust country. For the study, a qualitative research is used since the focus is on exploring and understanding what kind of decisions managers in a low trust country delegate and since the studies found on this phenomena were of quantities nature and did not give any specific information on what is and what is not delegated. The qualitative approach used to collect the data is the semistructured interview. The conclusion is in a low country, responsibilities and tasks are mainly delegated but not that much decision authority. Managers are delegating responsibilities as constructing the budget, the job description, interviewing, monitoring and evaluating employees, doing market research on suppliers and on promoting channels etc. As for decision authority, this is delegated just in the cases of promotions, choosing the person to be hired, handling customer complaints and negotiating sales terms. No decision authority is delegated in situations that have a financial implication for the company.

Joseph (2017) conducted a study entitled:" Effective Delegation of Authority as a Strategy for Task Accomplishment and Performance Enhanced in Business Organization - an empirical Survey of Flour Mills of Nigeria plc, LagosNigeria". This study aimed to determine the impact of effective delegation of authority as a strategy for task accomplishment and performance enhancement in business organizations, the population of the study comprises of staff of the flour mills of Nigeria plc, Lagos, Nigeria, totaled 2920 employee as at 2016. The sample size for the study is 352 employees. The first findings revealed that proper adoption of principles of delegation by the Flour Milles of Nigeria plc will enhance high performance output. The second findings revealed that obstacles and barriers to delegation if not property managed will impact negatively on performance output. The main proper recommendations are that, only qualified subordinates be assigned task to carry out and perform for quality decision making process. This is entailing that, Flour Mills of Nigeria plc should Endeavour to train her subordinate's staff to perform delegated task competently.

Al-Ani (2010) conducted a study entitled: "Delegation of Authority and its Impact on Job Performance in the Public Sector Hospitals in Jordan." This study aimed to identify the impact of all dimensions of the delegation of powers: delegation of authority, management control, style of leadership and management and decision-making on job performance in the public sector hospitals in Jordan. The researcher used appropriate statistical methods to analyze the study data, such as simple regression and multiple regressions, the (Z) Test and others. The population of the study included all hospital managers, their assistants and staff supervisors in (29) public sector hospitals in Jordan. The study sample included all members of the population of the study due to its relatively small size which included (304) people. To achieve the objectives of the study, the researcher developed a questionnaire whose validity and reliability have been verified. Results of this study showed that delegation of authority, management control, and style of leadership have positive effects on job performance and managerial decision-making in the public sector hospitals in Jordan.

'Ababneh and Al-Jama'an (2010) conducted a study entitled: "Attitudes of Oversight Departments Personnel towards the Influence of Accountability and Delegation of Authority: A Case Study of the Ministry of Education in Jordan." This study aimed to identify the role of accountability and delegation of authority in the decision-making 
process in the Ministry of Education in Jordan. The researchers designed a questionnaire that was distributed amongst (146) employees in management departments in the Ministry of Education. Results of this study showed that the level of the role of accountability and delegation of authority in management departments was high.

Muhanna's study (2006) "The Relationship between Delegation of Authority and the Effectiveness of Decision-making in Academic Departments from the Viewpoint of Faculty in Palestinian Universities" aimed to identify the effectiveness of the delegation of authority on managerial decision-making in academic departments in Palestinian universities. Population of the study included (1710) faculty members, PH.D and MA holders, in Palestinian universities (Bethlehem University, Bir Zeit University, Hebron University, the Arab American University, Al-Quds University, and An-Najah National University, during the academic year (2006). The stratified random study sample included (370) staff members, which accounted for approximately (21\%) of the study population. The researcher used the field descriptive approach and developed a survey questionnaire to collect data. Results of this study showed that the degree of the delegation of authority in academic departments from the viewpoint of faculty members in the Palestinian universities was very high, and that the effectiveness of the managerial decision-making in those universities was great. The study also revealed a positive correlation between the delegation of authority and the effectiveness of decision-making.

Mohammed Abu Rumman and et. al. (2013) investigated the impact of workplace environment on the average of job turnover in five-star hotels in Aqaba City in Jordan. Findings of the study showed that there is a statistically significant impact of the workplace environment on the average job turnover that can be attributed to the following factors: salary, interpersonal relationships with colleagues, health and safety system, the treatment of supervisor, delegation of authority, professional development training programs, justice at work, health insurance, housing allowance, promotion system, incentives, and transportation allowance. (126)

Naji's study (2005) aimed to investigate senior education administrators' practices of delegating powers to their subordinates and their relationship with efficient managerial decision-making in the Ministry of Education in Jordan. The population of the study consisted of (193) education administrators in the headquarters of the Ministry of Education and (576) education administrators in the education directorates for the academic year 2002/2003. The random sample consisted of (118) education administrators from the Ministry of Education / headquarters, and (219) administrators from its affiliated directorates. Results of the study showed that the educators' degree of understanding the benefits of delegation of authority was high, and that the degree of their practices of delegating powers to their subordinates was high as well. The results also showed that the level of the efficiency of managerial decision-making was high. Results also revealed that there is a positive relationship of statistical significance between the understanding of administrators to delegate authority and their practices, and the efficient managerial decision-making. Muneer Jaradat, et al. (2012) investigated the availability of accountability and responsibility in industrial companies in Aqaba City in Jordan. Findings of the study showed that most industrial companies in Aqaba have various delegations of authority centers where the performance of every center is supervised by a senior staff member assigned with the task of supervision and ensuring quality assurance (25-26).

In a study entitled "Management control systems and their effects on strategy formation at middle-management levels: evidence from a U.K. organization" David Marginson aimed to identify the impact of administrative control on the strategy in telecommunications companies in Britain. The study sample included (26) directors of middle management levels. The study showed that management oversight systems help develop new ideas in the company. The study also showed that management control has an impact on all activities of the organization especially on the strategies applied.

Yiannis E. Spanos (2002) investigated the relationship between information and communication technologies adoption and management. The study also aimed to shed light on the influence of telecommunication technology on the managerial decision-making in major Greek companies. The researcher distributed a questionnaire to a sample of (50) decision makers in companies throughout Greece. The results showed that the use of different types of information and communication technology leads to increased productivity and performance and extreme competition. The results also stressed the awareness of Greek companies of the importance of information technology and communications in enabling and supporting senior managers to take the right decisions and to delegate powers to their subordinates.

No manager can perform all the tasks assigned to him since he/she does not have enough time for all tasks. To achieve the objectives of the organization a senior manager should delegate authority to his subordinates. Delegation of Authority means distributing powers and the division of authority downwards to the manager's subordinate. To make delegation of authority effective, the manager should entrust some of his subordinates to do parts of his/her job. Delegation of authority entails the subdivision and the manager's sub-allocation of his powers to his subordinates to achieve the objectives of the organization. The absence of delegation of authority in any institution leads to the 
frustration of highly qualified staff that is faced with the lack of any opportunities for career growth and progress, job stress and alienation. Abu Rumman and et.al (2016) argue that many factors cause job alienation in the workplace mainly job stress, role conflict, role ambiguity and the absence of delegation of authority. (479)

Al-Sairafi (2003) defines delegation of authority as the manager's optional transfer of part of his authority to one of his subordinates, and this subordinate in turn becomes committed to perform the duties assigned to him by the manager. (Al-Helou 2010) Tuwaijri (2006) mentioned all the elements of the delegation of authority: first, duties assigned to the subordinate, or objectives that the subordinate granted delegation of authority must achieve. Second, powers delegated to the subordinate. This delegation of authority makes the subordinated employee entrusted with powers to take decisions and give instructions and orders to other employees on behalf of the manager. Responsibility refers to the duty of the subordinate to perform the task assigned to him efficiently and professionally without any delay. The subordinate entrusted with delegation of authority is accountable for any loss or damages that may befall the organization due to not performing his duties in the right way. Accountability means that the subordinate should give his manager justification for any variance in the actual performance of the task and the manager's expectations.

As for the manners of delegating powers, Dhiab (2004) pointed out that the manager may verbally ask his subordinate to perform certain tasks in the manner he or she sees appropriate. This gives the subordinate more freedom to perform the task as he /she wishes. This is considered as a verbal unlimited delegation of authority which allows the subordinate to exercise broad authority. On the other hand, delegation of authority can be written and documented. This method of delegating powers assigns limited tasks to the subordinate who is held accountable to the manager. Moreover, this type limits the disputes and differences that may occur between the manger and the subordinate entrusted with the delegation of authority. Mohammed Abu Rumman and Nadeen Al-Rahahalh (2016) investigated the impact of training programs and their strategies on the performance of the teaching and administrative staff Al-Balqa Applied University in Jordan. The study indicated that there is a statistically significant positive correlation between the commitment of senior management and the adoption of training strategy and the performance level of staff delegated with authority. (10-11)

Darwish and Al-Shammari (2010) mentioned the various benefits of the delegation of authority. Delegation of authority promotes the subordinates' loyalty to their organization, encourages them to work as one team, enhances the manager's trust among his subordinates, and gives subordinates the opportunity to professionally develop themselves and show off their innovation and creativity. In addition, delegation of authority relieves managers of the burden of performing simple tasks and thus gives them enough time to perform other vital tasks related to policy-making, supervision and guidance, instead of wasting time doing work that could be done by their subordinates.

Moreover, delegating authority to highly qualified staff increases their productivity and job satisfaction which in turn positively affects the profits and revenues of a company. Mohammed Abu Rumman (2011) conducted a study in which he investigated the factors affecting job satisfaction among staff working in travel and tourism agencies in Amman. Findings of the study showed that job satisfaction among staff in tourist agencies is related to many factors such as financial incentives granted to staff, professional development training programs, delegation of authorities, and positive relationship between staff and managers. (89-90)

The main obstacles that prevent the implementation of the delegation of authority in most organizations are that most managers mistakenly believe that they are and no one else can perform tasks properly. Moreover, some senior managers fear of the superiority of their subordinates if assigned with certain tasks. In addition, some managers fear losing the experience they gained from performing their managerial tasks. Some managers also lack the required level of professional capacity and the awareness of other people's capabilities. They fear that their subordinates will expose their weakness in management. Some subordinates also lack professionalism and do not accept to be granted delegation of authority. Such subordinates lack confidence in themselves. What makes things more difficult for subordinates to accept delegation of authority is the lack of adequate incentives for each performed task (Najy, 2005).

Delegation of authority is always influenced by the level of management control over the lower administrative levels. The manager has the right to monitor the actions of individuals on delegated authority (Harb, 2011). Abu Khairan (2011) and Al-Harbi (2007) recommended resorting to regulatory effective ways of monitoring subordinates granted delegation of authority. Abu Khairan (2011) discussed many obstacles that prevent the implementation of the delegation of authority in some organizations. The most serious obstacle is the lack of means of communication, technology, management control and supervision. The failure to provide these methods makes the manager reluctant to delegate powers to his subordinates due to the fact that he will not be able to supervise and directly monitor the workflow. 


\subsection{Management Control}

The function of management control is an ongoing process and goes hand in hand with management functions that begin with planning, organization and coordination, and then implementation and follow-up. This requires employing qualified human resources staff to perform the required follow-up and control tasks to achieve the desired objectives (Ababneh and Al- Jama'an, 2010). Administrative control is the process by which senior managers make sure that what has been planned is what has already been done and then take corrective action to achieve the desired objectives (Jadba, 2007).

There are many conditions that must be met in order to achieve management control and maximize its effectiveness. Among these conditions is the organizational structure of a company. The more obvious the organizational structure is, the more efficient management control becomes and consequently senior managers will be more able to achieve the desired objectives. Communication through proper channels among staff and their subordinates is necessary for successful management control. A successful senior manager is the one who spends part of his time communicating with his subordinates for consultations, the exchange of information and ideas. In addition, the assessment process is considered one of the most important pillars and fundamentals upon which to build management control. Feedback and evaluation improve work performance because they help compare actual performance with the desired performance and help decision makers take corrective action to deal with deviations. To achieve management control efficiency senior managers should be provided with all the means necessary for the implementation of administrative control such as personal observation, written reports and supervision through direct communication with their subordinates (Farra and Shaheen, 2009). Management control activates the process of decision-making as it provides senior managers with reliable data about actual work performance and sheds light on the obstacles that hinder taking the appropriate decisions (Harbi, 2003).

\subsection{Effectiveness of Decision-Making}

The decision-making process is one of the most basic indicators for successful management and the most important elements inherent in the work of senior managers. An organization's administrative decisions reveal its success or failure, and help the organization achieve its desired objectives (Ghazali, 2012). The administrative decision-making process contains three basic elements: first is the choice: the senior manager might have to choose between several decisions or he might be faced with limited choices for making a decision. Sometimes, the decision- maker faces a number of limitations and restrictions on the decisions he has to make. These can be economic, political or social factors that restrict the decision making process. Second are the alternatives: the senior manager might be faced with wide a range of alternative decisions when he must take one appropriate decision. This forces him to exclude many decisions to take the most appropriate one in light of the financial and human resources available to him. Third are the motives and objectives of taking the most appropriate decision. The effectiveness of decisions is always based on strong motivation (Delilah, 2011).

The decision-making process passes through a number of stages starting with the diagnosis of the problem since a wrong diagnosis of a problem leads to a wrong decision. The second stage includes the collection of data about the problem, and then finding alternative solutions. The third stage includes evaluating the alternatives available to solve the problem and, finally, choosing the most appropriate solution to the problem (Mattar, 2008).

The researchers of this study confirm that delegation of authority does not bear fruit without an internal management control system that evaluates the process and takes corrective measures for deviations. Management control helps senior managers monitor the work performance of subordinates delegated with powers. This is done only with the availability of the means necessary for personal communication between the senior managers and subordinates granted delegation of authority to perform tasks. This instant communication between senior managers and subordinates delegated with powers helps make the required data available when requested. Management control serves the purpose of enabling senior managers to take appropriate decisions in a timely manner. Managerial decision making is a very accurate process based on precise data that subordinates provide to senior managers in a timely manner. Both delegation of authority and control management lead to effective managerial decision making which in turn helps achieve the desired objectives of an organization.

\section{Research Methodology}

\subsection{Study Sample and Population}

The study sample included all senior managers in the two branches of the Arab Pharmaceutical Manufacturing Company in Al-Salt City in Jordan- Hussein Pharmaceutical Manufacturing Factory with a study sample totaling (122) senior staff and Buhaira Pharmaceutical Manufacturing Factory with a study sample totaling (164) senior staff. Thus, 
the study sample included all managers from the two branches totaling (286). The survey questionnaires were distributed among the study sample. While (237) completed questionnaires were filled in and returned to the researchers, the (21) incomplete questionnaires were excluded. Thus, the number of questionnaires convenient for analysis was (252) with a recovery $(88.1 \%)$, which is a statistically acceptable ratio.

\subsection{Instrument of the Study}

The researchers used the questionnaire as a tool for the purpose of collecting data from the study sample. The five-point Likert Scale was used to respond to the items of the questionnaire whereby the rating ranged from (5) which means (strongly agree) to (1), which means (strongly disagree). The survey questionnaire consisted of (29) items divided into three parts. Previous studies (Al-Helou 2010; Muhanna, 2006) were used to help design the items of the questionnaire. The first part contains data on the demographic factors of the study sample (gender, age, educational qualifications, and years of experience and job title). The second part was devoted to measure the independent variables; delegation of authority, which covered items (1-8), and the management control variable, which covered items (9-17). The third part was devoted to measure the effectiveness of managerial decisions dependent variable, which covered items (18-29).

\subsection{Validity and Consistency of the Study Instrument}

The researchers tested the stability and consistency of the survey questionnaire and its ability to measure the variables by using Cronbach's Coefficient Alpha. The result of the test becomes statistically acceptable if the value of Cronbach's alpha is greater than (0.60) (Sekaran and Bougie, 2010). The closer the result reaches 100\% the higher the degree of the instrument's stability becomes. The internal consistency of Cronbach's coefficient alpha was used to test the variables of the study and its domains and the study instrument as a whole. This was done to check the consistency in the respondents' answers as shown in Table 1.

Table 1. Internal consistency coefficient values

\begin{tabular}{ll}
\hline Dimension & Alpha Value \\
\hline Delegation of Authority & 0.876 \\
\hline Management Control & 0.805 \\
\hline Effectiveness of Decision-making & 0.891 \\
\hline All Items & 0.867 \\
\hline
\end{tabular}

Results of the questionnaire's reliability as shown in Table 1 reveal that the internal consistency coefficient Cronbach's alpha for all the items ranged between $(0.805-0.891)$. The alpha value for all items stood at $(0.867)$. Therefore, it becomes clear that all values are higher than the conventional stability measure (0.60), and this confirms the reliability and consistency between the items of the questionnaire and consequently proves the suitability of the study instrument for statistical analysis.

\subsection{Statistical Methods}

The researchers used many statistical methods to analyze the data and test the hypotheses related to the study sample: frequencies, percentages, means scores, and standard deviations. However, to test the validity, consistency and reliability of the study instrument and to test the hypotheses of the study, other statistical methods were used such as the Alpha Cronbach Test, simple regression, multiple regressions, and hierarchical regression.

\subsubsection{Statistical Analysis and Testing Hypotheses}

This part presents a description and analysis of the study data, characteristics of the study sample, the variables, the percentage significance of the items of the survey questionnaire, an analysis of the respondents' answers to the survey questions, and testing hypotheses.

\subsection{Characteristics of the Study Sample}

This part contains a description of the demographic characteristics of members of the study sample, namely: gender, age, educational qualifications, years of experience, and position title. To do this, the frequencies, and percentages of the demographic variables for members of the study sample was calculated as follows: 


\subsubsection{Gender}

Table 2. Distribution of individuals in the study sample according to the gender variable

\begin{tabular}{llll}
\hline Variable & Gender & Frequency & Percentage \\
\hline Gender & Male & 106 & 42.1 \\
\cline { 2 - 4 } & Female & 146 & 57.9 \\
\cline { 2 - 4 } & Total & 252 & 100 \\
\hline
\end{tabular}

As shown in Table 2 the female ratio constitutes $(57.9 \%)$ of the study sample, while males constitute a proportion $(42.1 \%)$ of the sample.

\subsubsection{Age}

Table 3. Distribution of the individuals in the study sample according to the age variable

\begin{tabular}{llll}
\hline Variable & Category & Frequency & Percentage \\
\hline Age & less than 20 years & 10 & 4.0 \\
\hline & $\mathbf{2 0}$ - less than 35 years & 87 & 34.5 \\
\hline $\mathbf{3 5}$ - less than 40 years & 105 & 41.7 \\
\hline $\mathbf{4 5}$ years and above & 50 & 19.8 \\
\hline Total & 252 & 100
\end{tabular}

As shown in Table 3 the age group (less than 20 years) is the lowest category, which accounted for (4.0\%) while the age group (35 - less than 40 years) is the largest and by (41.7\%).

\subsubsection{Educational Qualifications}

Table 4. Distribution of the individuals in the study sample according to the educational qualifications variable

\begin{tabular}{llll}
\hline Variable & Category & Frequency & Percentage \\
\hline & less than secondary school certificate & 19 & 7.5 \\
\cline { 2 - 4 } & secondary school certificate & 30 & 11.9 \\
\cline { 2 - 4 } & two-year Community college diploma & 56 & 22.2 \\
\cline { 2 - 4 } $\begin{array}{l}\text { Educational } \\
\text { Qualifications }\end{array}$ & Bachelor's Degree & 124 & 49.2 \\
\cline { 2 - 4 } & Master's Degree & 18 & 7.1 \\
\cline { 2 - 4 } & PH.D & $\mathbf{5 2}$ & 2.0 \\
\cline { 2 - 4 } & Total & $\mathbf{2 5 2}$ & $\mathbf{1 0 0}$ \\
\hline
\end{tabular}

As shown in Table 4 (BA) holders have formed the largest proportion, reaching (49.2\%). 


\subsubsection{Years of Experience}

Table 5. Distribution of the individuals in the study sample according to the years of experience variable

\begin{tabular}{llll}
\hline Variable & Category & Frequency & Percentage \\
\hline & less than 5 years & 32 & 12.7 \\
\cline { 2 - 4 } Years of & 5 years - less than 10 years & 93 & 36.9 \\
\cline { 2 - 4 } Experience & 10 years and above & 127 & 50.4 \\
\cline { 2 - 4 } & Total & $\mathbf{2 5 2}$ & $\mathbf{1 0 0}$ \\
\hline
\end{tabular}

As shown in Table 5 the respondents have a relatively long work experience. Workers with less than 5 years experience have accounted for the least ratio reaching (12.7\%), while the rest of the categories gained at a higher rate.

3.5.5 Position Title

Table 6. Distribution of the individuals in the study sample according to the position title variable

\begin{tabular}{llll}
\hline Variable & Category & Frequency & Percentage \\
\hline & Department Director & 10 & 4.0 \\
\cline { 2 - 4 } Position Title & Deputy Department Director & 16 & 6.3 \\
\cline { 2 - 4 } & Department Head & 21 & 8.3 \\
\cline { 2 - 4 } & Unit Head & 37 & 14.7 \\
\cline { 2 - 4 } & Supervisor & 168 & 66.7 \\
\cline { 2 - 4 } & Total & $\mathbf{2 5 2}$ & $\mathbf{1 0 0}$ \\
\hline
\end{tabular}

As shown in Table 6 the category (Department Director) constituted a minor category, and by (4.0\%), while the percentage of the category (Supervisor) constituted the major category, and by (66.7\%).

\section{Data Analysis}

This part of the study presents a description of the variables of the study and the items of the survey questionnaire. The means scores and the standard deviations for all items of the questionnaire have been calculated in order to judge the degree of approval, and determine the relative importance for each item. The results were as follows:

\subsection{Delegation of Authority}

Table 7. Scores, and standard deviations of the survey questionnaire items related to delegation of authority

\begin{tabular}{llllll}
\hline No. & Item & Means Score & $\begin{array}{l}\text { Standard } \\
\text { Deviation }\end{array}$ & Level & $\begin{array}{l}\text { Percentage } \\
\text { Significance }\end{array}$ \\
\hline 1 & $\begin{array}{l}\text { Follow-up of subordinates assigned with } \\
\text { authority of delegation in the factory }\end{array}$ & 3.984 & 0.763 & 2 & High \\
\hline 2 & $\begin{array}{l}\text { Delegating powers to subordinates in } \\
\text { conformity with their capabilities }\end{array}$ & 4.036 & 0.743 & 1 & High \\
\hline 3 & $\begin{array}{l}\text { Manager makes sure of the ability of a } \\
\text { subordinate to use the powers delegated to } \\
\text { him }\end{array}$ & 3.631 & 1.027 & 8 & Average \\
\hline 4 & Manager gives the subordinate freedom to & 3.944 & 0.882 & 3 & High \\
\hline
\end{tabular}




\begin{tabular}{|c|c|c|c|c|c|}
\hline & \multicolumn{5}{|l|}{ perform the tasks assigned to him } \\
\hline 5 & $\begin{array}{l}\text { Manager trains subordinate to perform the } \\
\text { delegated task before starting work }\end{array}$ & 3.845 & 1.058 & 5 & High \\
\hline 6 & $\begin{array}{l}\text { Manager allows a subordinate to exercise } \\
\text { initiative and innovation in the completion } \\
\text { of tasks delegated to him }\end{array}$ & 3.659 & 1.112 & 7 & Average \\
\hline 7 & $\begin{array}{l}\text { Manager specifies the expected objectives } \\
\text { and results for the subordinate delegated } \\
\text { with powers }\end{array}$ & 3.758 & 0.998 & 6 & High \\
\hline 8 & $\begin{array}{l}\text { Manager clarifies the limits of the powers } \\
\text { delegated to a subordinate }\end{array}$ & 3.849 & 1.188 & 4 & High \\
\hline & ral Assessment & 3.838 & 0.635 & & High \\
\hline
\end{tabular}

We notice from the above table that the relative importance of the average means scores of the items pertaining to delegation of authority was high, whereas the overall means score stood at (3.838) and the standard deviation reached (0.635). The item "delegating powers to subordinates in conformity with their capabilities" ranked first with a mean score (4.036) and with a high percentage significance. While the item "The manager makes sure of the ability of a subordinate to use the powers delegated to him," gained the last rank with a means score (3.631), and an average percentage significance.

\subsection{Control Management}

Table 8. Scores and standard deviations of the survey questionnaire items related to management control

\begin{tabular}{llllll}
\hline No. & Item & $\begin{array}{l}\text { Means } \\
\text { Score }\end{array}$ & $\begin{array}{l}\text { Standard } \\
\text { Deviation }\end{array}$ & Level & $\begin{array}{l}\text { Percentage } \\
\text { Significance }\end{array}$ \\
\hline $\mathbf{9}$ & $\begin{array}{l}\text { There is a management control system in the } \\
\text { factory }\end{array}$ & 3.794 & 1.036 & 3 & High \\
\hline $\mathbf{1 0}$ & $\begin{array}{l}\text { The management control system in the factory } \\
\text { is visible and clear to everyone }\end{array}$ & 3.706 & 1.445 & 6 & High \\
\hline $\mathbf{1 1}$ & $\begin{array}{l}\text { Senior managers discuss feedback from } \\
\text { beneficiaries of the factory's products }\end{array}$ & 3.786 & 1.049 & 4 & High \\
\hline $\mathbf{1 2}$ & $\begin{array}{l}\text { The managers make sure that the objectives of } \\
\text { the desired plans can be achieved }\end{array}$ & 3.544 & 1.234 & 9 & Average \\
\hline $\mathbf{1 3}$ & $\begin{array}{l}\text { Outstanding employees are encouraged with } \\
\text { incentives }\end{array}$ & 3.671 & 1.347 & 8 & High \\
\hline $\mathbf{1 4}$ & $\begin{array}{l}\text { The factory management uses written reports to } \\
\text { evaluate work performance }\end{array}$ & 3.683 & 1.282 & 7 & High \\
\hline $\mathbf{1 5}$ & $\begin{array}{l}\text { Personal observation leads to improved work } \\
\text { performance }\end{array}$ & 4.040 & 1.118 & 1 & High \\
\hline $\mathbf{1 6}$ & $\begin{array}{l}\text { Deviations from the factory's objectives are } \\
\text { corrected promptly }\end{array}$ & 3.778 & 1.156 & 5 & High \\
\hline $\mathbf{1 7}$ & $\begin{array}{l}\text { Feedback from staff, senior managers and } \\
\text { beneficiaries is used to improve work } \\
\text { performance }\end{array}$ & $\mathbf{3 . 7 5 1 7}$ & 1.021 & 2 & High \\
\hline $\mathbf{G e n e r a l ~ A s s e s s m e n t ~}$ & $\mathbf{0 . 7 3 1}$ & High \\
\hline
\end{tabular}


We notice from the above table that the percentage significance of the means scores of the items pertaining to management control was high, where the overall means score stood at (3.757) with a standard deviation (0.731). The item was "personal observation leads to improved work performance," ranked first with a means score (4.040) and a high percentage significance. While the item "the managers make sure that the objectives of the desired plans can be achieved," gained the last rank with a means score (3.544), and an average percentage significance.

\subsection{Effectiveness of Decision-Making}

Table 9. Scores and standard deviations of the survey questionnaire items related to the effectiveness of decision-making

\begin{tabular}{|c|c|c|c|c|c|}
\hline No. & Item & $\begin{array}{l}\text { Means } \\
\text { Score }\end{array}$ & $\begin{array}{l}\text { Standard } \\
\text { Deviation }\end{array}$ & Level & $\begin{array}{l}\text { Percentage } \\
\text { Significance }\end{array}$ \\
\hline 18 & $\begin{array}{l}\text { I make decisions in line with the objectives } \\
\text { of the factory }\end{array}$ & 4.024 & 1.164 & 3 & High \\
\hline 19 & $\begin{array}{l}\text { The decision I make help achieve the desired } \\
\text { objectives }\end{array}$ & 3.603 & 1.324 & 12 & Average \\
\hline 20 & $\begin{array}{l}\text { I chose the easier alternative for practical } \\
\text { solutions when making my decisions }\end{array}$ & 3.782 & 1.251 & 10 & High \\
\hline 21 & $\begin{array}{l}\text { Workers do not face major obstacles in the } \\
\text { implementation of the decisions I make. }\end{array}$ & 3.746 & 1.194 & 11 & High \\
\hline 22 & I take decisions in a timely manner & 4.020 & 1.088 & 4 & High \\
\hline 23 & I have the ability to make quick decisions & 3.829 & 1.005 & 9 & High \\
\hline 24 & $\begin{array}{l}\text { The decisions I make receive acceptance } \\
\text { among relevant personnel }\end{array}$ & 4.060 & 0.784 & 1 & High \\
\hline 25 & I consult staff before making decisions & 3.853 & 1.078 & 8 & High \\
\hline 26 & $\begin{array}{l}\text { I make sure that I have all the necessary } \\
\text { information when making a decision }\end{array}$ & 3.877 & 0.972 & 7 & High \\
\hline 27 & $\begin{array}{l}\text { I make sure that staff has the knowledge } \\
\text { necessary to implement the decisions } \\
\text { entrusted to them }\end{array}$ & 4.000 & 1.108 & 5 & High \\
\hline 28 & $\begin{array}{l}\text { I give workers the opportunity to discuss the } \\
\text { decisions I make }\end{array}$ & 3.984 & 0.763 & 6 & High \\
\hline 29 & $\begin{array}{l}\text { I feel good about the results of the decisions } \\
\text { I make }\end{array}$ & 4.036 & 0.743 & 2 & High \\
\hline \multicolumn{2}{|c|}{ General Assessment } & 3.901 & 0.592 & & High \\
\hline
\end{tabular}

We notice from the above table that the percentage significance of the means scores of all the items related to the effectiveness of decision-making was high with an overall means score (3.901) and a standard deviation (0.592). The item "the decisions I make receive acceptance among relevant personnel" ranked first with a means score (4.060) and a high percentage significance, while the item "the decision I make help achieve the desired objectives" gained the last rank with a means score (3.603), and an average percentage significance.

\subsection{Testing Hypotheses}

The first and the second hypotheses have been analyzed using the simple linear regression, while the third and fourth hypotheses have been analyzed using the hierarchical regression. The results were as follows:

The First Hypothesis: Delegation of authority has no statistically significant effect at the level $a \leq 0.05$ on the effectiveness of managerial decision-making in the Arab Pharmaceutical Manufacturing Company in Al-Salt City in Jordan. 
Table 10. Test results-influence of delegation of authority on the effectiveness of the decision-making

\begin{tabular}{|c|c|c|c|c|c|c|c|c|c|}
\hline \multirow[b]{2}{*}{$\begin{array}{l}\text { Dependent } \\
\text { Variable }\end{array}$} & \multicolumn{2}{|c|}{ Model Summery } & \multicolumn{2}{|l|}{ ANOVA } & \multicolumn{5}{|c|}{ Coefficient Table } \\
\hline & $\begin{array}{l}\mathbf{R} \\
\text { Correlation } \\
\text { Coefficient }\end{array}$ & $\begin{array}{l}\mathbf{r}^{2} \\
\text { Adjusted } \\
\mathbf{R} \\
\text { Square }\end{array}$ & $\mathbf{F}$ & $\begin{array}{l}\text { Sig } \\
\text { F* }^{*}\end{array}$ & description & B & $\begin{array}{l}\text { Standard } \\
\text { Error }\end{array}$ & $\mathrm{T}$ & $\begin{array}{l}\text { Sig } \\
t^{*}\end{array}$ \\
\hline $\begin{array}{l}\text { effectiveness of } \\
\text { decision-making }\end{array}$ & 0.701 & 0.491 & 240.978 & 0.000 & $\begin{array}{l}\text { delegation } \\
\text { of authority }\end{array}$ & 0.653 & 0.042 & 15.523 & 0.000 \\
\hline
\end{tabular}

The results shown in Table (10) reveal that the value $(\mathrm{r}=0.701)$, and this means that there is a positive relationship between delegation of authority and the effectiveness of decision-making. It turns out that the value of the adjusted square $(\mathrm{r} 2=0.491)$. This means that delegation of authority has amounted to $(49.1 \%)$ of the variance in the effectiveness of decision-making, while the other factors remaining stable and constant. As shown in the above table the value of $(\mathrm{F})$ has reached $(240.978)$ at the confidence level $(\mathrm{Sig}=0.000)$ and this confirms a significant gradient at the level of $(\alpha \leq 0.05)$. The table also shows that the value $(B=0.653)$ and value $(t=15.523)$ at a confidence level (Sig $=0.000$ ) and this confirms a positive correlation at the level of

$(\alpha \leq 0.05)$. Based on the foregoing argument, the first hypothesis is rejected and its antithesis hypothesis is accepted: "delegation of authority has a statistically significant effect at the level $a \leq 0.05$ on the effectiveness of managerial decision-making in the Arab Pharmaceutical Manufacturing Company in Al-Salt City in Jordan.

The Second Hypothesis: Management control has no statistically significant effect at the level a $\leq 0.05$ on the effectiveness of managerial decision-making in the Arab Pharmaceutical Manufacturing Company in Al-Salt City in Jordan.

Table 11. Test results-influence of management control on the effectiveness of the decision-making

\begin{tabular}{|c|c|c|c|c|c|c|c|c|c|}
\hline \multirow[b]{2}{*}{$\begin{array}{l}\text { Dependent } \\
\text { Variable }\end{array}$} & \multicolumn{2}{|c|}{ Model Summery } & \multicolumn{2}{|c|}{ ANOVA } & \multicolumn{5}{|c|}{ Coefficient Table } \\
\hline & $\begin{array}{l}\mathbf{R} \\
\text { Correlation } \\
\text { Coefficient }\end{array}$ & $\begin{array}{l}\mathbf{r}^{2} \\
\text { Adjusted } \\
\mathbf{R} \\
\text { Square }\end{array}$ & $\mathbf{F}$ & $\begin{array}{l}\text { Sig } \\
\text { F* }^{*}\end{array}$ & description & B & $\begin{array}{l}\text { Standard } \\
\text { Error }\end{array}$ & $\mathrm{T}$ & Sig t* \\
\hline $\begin{array}{l}\text { effectiveness of } \\
\text { decision-making }\end{array}$ & 0.242 & 0.059 & 15.596 & 0.000 & $\begin{array}{l}\text { management } \\
\text { control }\end{array}$ & 0.196 & 0.050 & 3.949 & 0.000 \\
\hline
\end{tabular}

Results in Table 11 show that the value $(\mathrm{r}=0.242)$. This means that there is a positive relationship between management control and the effectiveness of decision-making. It turns out that the value of the adjusted square $(\mathrm{r} 2=$ 0.059), and this means that management control has amounted to (5.9\%) of the variation in the effectiveness of decision-making while the other factors remaining constant and stable. As shown in the above table the value of (F) has reached $(15.596)$ at the confidence level $(\mathrm{Sig}=0.000)$ and this confirms a significant gradient at the level of $(\alpha \leq 0.05)$. The above table also shows that the value $(\mathrm{B}=0.196)$ and value $(\mathrm{t}=3.949)$ at a confidence level $(\mathrm{Sig}=0.000)$ and this confirms a positive correlation at the level of $(\alpha \leq 0.05)$. Based on the foregoing argument, the second hypothesis is rejected and the following alternative antithesis hypothesis is hereby accepted: "Management control has a statistically significant effect at the level $\mathrm{a} \leq 0.05$ on the effectiveness of managerial decision-making in the Arab Pharmaceutical Manufacturing Company in Al-Salt City in Jordan."

The Third Hypothesis: Delegation of authority and control management have no statistically significant effect at the level $a \leq 0.05$ on the effectiveness of managerial decision-making in the Arab Pharmaceutical Manufacturing Company in Al-Salt City in Jordan attributable to demographic factors: gender, age, job title, educational qualification, and number of years of experience. 
Table 12. Results of the hierarchical regression show that there are statistically significant differences in the impact of delegation of authority on the effectiveness of decision-making attributable to demographic variables

\begin{tabular}{|c|c|c|c|c|c|c|c|}
\hline \multirow[b]{2}{*}{$\begin{array}{l}\text { Dependent } \\
\text { Variable }\end{array}$} & \multirow{2}{*}{$\begin{array}{l}\text { Independent } \\
\text { Variables }\end{array}$} & \multicolumn{3}{|l|}{ Step One } & \multicolumn{3}{|c|}{ Step Two } \\
\hline & & B & $\begin{array}{l}\text { Calculated } \\
\text { T. Value }\end{array}$ & Sig $t$ & B & $\begin{array}{l}\text { Calculated } \\
\text { T. Value }\end{array}$ & Sig $t$ \\
\hline \multirow{10}{*}{$\begin{array}{l}\text { Effectiveness } \\
\text { of Decision } \\
\text {-making }\end{array}$} & $\begin{array}{l}\text { Delegation of } \\
\text { Authority }\end{array}$ & 0.635 & 15.523 & 0.000 & 0.652 & 15.341 & 0.000 \\
\hline & Gender & & & & 0.077 & 1.380 & 0.169 \\
\hline & Age & & & & 0.104 & 3.109 & 0.002 \\
\hline & $\begin{array}{l}\text { Years of } \\
\text { Experience }\end{array}$ & & & & 0.010 & 0.263 & 0.793 \\
\hline & $\begin{array}{l}\text { Educational } \\
\text { Qualifications }\end{array}$ & & & & 0.052 & 2.086 & 0.038 \\
\hline & Position Title & & & & 0.003 & 0.111 & 0.912 \\
\hline & $\begin{array}{l}\mathbf{R}^{2} \text { Adjusted } \mathbf{R} \\
\text { Square }\end{array}$ & 0.491 & & & 0.522 & & \\
\hline & $\Delta \mathbf{R}^{2}$ & 0.491 & & & 0.031 & & \\
\hline & $\Delta \mathbf{F}$ & 240.978 & & & 3.157 & & \\
\hline & $\operatorname{Sig} \Delta F$ & 0.000 & & & 0.009 & & \\
\hline
\end{tabular}

Table 12 shows the results of the hierarchical regression based on applying the two models. The first model-based results as shown in the first step reveal that delegation of authority has a statistically significant effect on managerial decision-making, where the value of $(\Delta F=240.978)$ and the level of significance ( $\operatorname{Sig} \Delta F=0.000)$ which is less than 0.05 , and the value of the adjusted square $(\mathrm{R} 2=0.491)$. This indicates that delegation of authority accounted for $(49.1 \%)$, of the variance in the effectiveness of the decision-making. In the second step, the demographic variables have been introduced to the regression model, where the value of the adjusted square R2 increased by (3.1\%). This percentage is statistically significant where the value $(\Delta F=3.157)$ and the level of significance is ( $\operatorname{Sig} \Delta \mathrm{F}=0.009)$ which is less than (0.05). The (B) value for the age and educational qualifications variables had a statistically significant effect, while the rest of the values did not show a significant effect. Therefore, it becomes clear that the differences are attributable to these two variables. Consequently, the third hypothesis is rejected and the following antithesis hypothesis is accepted as an alternative: "Delegation of authority has a statistically significant effect at the level $\leq \leq 0.05$ on the effectiveness of managerial decision-making in the Arab Pharmaceutical Manufacturing Company in Al-Salt City in Jordan attributable to demographic factors: gender, age, job title, educational qualification, and number of years of experience)."

The Fourth Hypothesis: Control management has no statistically significant effect at the level $a \leq 0.05$ on the effectiveness of managerial decision-making in the Arab Pharmaceutical Manufacturing Company in Al-Salt City in Jordan attributable to demographic factors: gender, age, job title, educational qualification, and number of years of experience.

Table 13. Results of the hierarchical regression show that there are statistically significant differences in the impact of management control on the effectiveness of decision-making attributable to demographic variables

\begin{tabular}{|c|c|c|c|c|c|c|c|}
\hline \multirow{2}{*}{$\begin{array}{l}\text { Dependent } \\
\text { Variable }\end{array}$} & \multirow{2}{*}{$\begin{array}{l}\text { Independent } \\
\text { Variables }\end{array}$} & \multicolumn{3}{|l|}{ Step One } & \multicolumn{3}{|c|}{ Step Two } \\
\hline & & B & $\begin{array}{l}\text { Calculated } \\
\text { T. Value }\end{array}$ & Sig $\mathbf{t}$ & B & $\begin{array}{l}\text { Calculated } \\
\text { T. Value }\end{array}$ & Sig $\mathbf{t}$ \\
\hline \multirow{2}{*}{$\begin{array}{l}\text { Effectiveness } \\
\text { of Decision } \\
\text {-making }\end{array}$} & $\begin{array}{l}\text { Management } \\
\text { Control }\end{array}$ & 0.196 & 3.949 & 0.000 & 0.652 & 15.341 & 0.000 \\
\hline & Gender & & & & 0.211 & 4.267 & 0.000 \\
\hline
\end{tabular}




\begin{tabular}{lllll} 
Age & & $\mathbf{- 0 . 2 3 0}$ & $\mathbf{- 3 . 0 5 4}$ & $\mathbf{0 . 0 0 3}$ \\
\hline $\begin{array}{l}\text { Years of } \\
\text { Experience }\end{array}$ & & $\mathbf{0 . 0 6 0}$ & $\mathbf{1 . 3 2 5}$ & $\mathbf{0 . 1 8 6}$ \\
\hline $\begin{array}{l}\text { Educational } \\
\text { Qualifications }\end{array}$ & & $\mathbf{0 . 0 6 9}$ & $\mathbf{1 . 2 9 8}$ & $\mathbf{0 . 1 9 5}$ \\
\hline $\begin{array}{l}\text { Position Title } \\
\text { R2 Adjusted R }\end{array}$ & $\mathbf{0 . 0 5 9}$ & $\mathbf{0 . 0 9 6}$ & $\mathbf{2 . 8 6 5}$ & $\mathbf{0 . 0 0 5}$ \\
\begin{tabular}{l} 
Square \\
\hline R2
\end{tabular} & $\mathbf{0 . 0 5 9}$ & $\mathbf{0 . 1 2 7}$ & & \\
\hline$\Delta \mathrm{F}$ & $\mathbf{1 5 . 5 9 6}$ & $\mathbf{0 . 0 6 8}$ & & \\
\hline Sig $\Delta \mathrm{F}$ & $\mathbf{0 . 0 0 0}$ & $\mathbf{3 . 8 3 2}$ & & \\
\hline
\end{tabular}

The above table shows the results of the hierarchical regression based on applying the two models. As shown in the above table, the first model-based results gained from the first step reveal that management control has a statistically significant effect on the effectiveness of decision-making, where the value of $(\Delta F=15.596)$ and the level of significance ( $\operatorname{Sig} \Delta \mathrm{F}=0.000)$ which is less than 0.05 , and the value of adjusted square reached $(\mathrm{R} 2=0.059)$. This indicates that management control amounted to (5.9\%) of the variance in the effectiveness of the decision-making. In the second step the demographic variables were introduced to the hierarchical regression model, whereby the value of the adjusted square $\mathrm{R} 2$ increased by $(6.8 \%)$, and this percentage is statistically significant since the value $(\Delta \mathrm{F}=3.832)$ and the level of significance ( $\operatorname{Sig} \Delta \mathrm{F}=0.002$ ) which is less than 0.05 . The (B) value for the gender variable was negative, and the educational qualifications variable had a statistically significant effect, while the rest of the values did not show a positive effect. This shows that the differences are attributable to these two variables. Accordingly, the fourth hypothesis is rejected, while the following antithesis hypothesis is accepted as an alternative: "control management has a statistically significant effect at the level $\mathrm{a} \leq 0.05$ on the effectiveness of managerial decision-making in the Arab Pharmaceutical Manufacturing Company in Al-Salt City in Jordan attributable to demographic factors: gender, age, job title, educational qualification, and number of years of experience."

\section{Results of the Study}

Based on the analysis of data and testing the hypotheses, the study concluded with the following results:

1. Senior managers of the Arab Pharmaceutical Manufacturing Company Limited in Al-Salt city in Jordan delegate powers to their subordinates with a high degree. They take into account the capabilities of the subordinates who have been delegated to perform tasks.

2. In the Arab Pharmaceutical Manufacturing Company management control of the performance of the subordinates delegated with powers is done by senior managers through personal observation. This leads to the improvement of work performance.

3. The effectiveness of the decisions taken by the decision makers in the Arab Pharmaceutical Manufacturing Company is obvious and this is indicated by their suitability for achieving the objectives of the factory and in that it is widely popular among workers in the factory.

4. The impact of delegation of authority on the effectiveness of decision-making in the Arab Pharmaceutical Manufacturing Company is statistically significant. Delegating powers to subordinates reduces a large part of the burden on senior managers, allowing them to perform major tasks and select suitable alternatives when making decisions.

5. The impact of management control on the effectiveness of decision-making in the Arab Pharmaceutical Manufacturing Company is statistically significant as it allows managers to compare between the actual work performance and the planned performance. It also assists managers in selecting appropriate alternatives when making decisions. This in turn helps managers to correct deviations.

6. There are statistically significant differences attributed to the impact of both delegation of authority and management control on the effectiveness of management decision-making in the Arab Pharmaceutical Manufacturing Company that can be attributed to demographic variables: gender, age, educational qualification, job title, and years of experience. 


\section{Limitations, Recommendation for Further Studies}

This study is limited present the influence of delegation of authority and administrative control on the effectiveness of managerial decisions in the Arab Pharmaceutical Manufacturing Company Limited in Al-Salt city. Another limitation is that only (286) employees in the Arab Pharmaceutical Manufacturing Company Limited in Al-Salt city were the sample of the study. Therefore, the findings of this study cannot be generalized beyond this sample.

This study recommends further investigation in influence of delegation of authority and administrative control on the effectiveness of managerial decisions of different sectors in Jordan to verify or refute the findings of this study. Moreover, this study recommends that more studies should be conducted to investigate the impact of delegation of authority on other variables such as work performance and productivity. The researchers recommend that senior managers need to realize the importance of delegating powers to their subordinates and its effect on improving work performance and the need to use various forms of management control to achieve the desired objectives of the organization.

\section{References}

Ababneh, R., \& Al-Jama'an, N. (2010). Attitudes of Oversight Departments Personnel towards the Influence of Accountability and Delegation of Authority: A Case Study of the Ministry of Education in Jordan. Dirasat, $37(2), 388-407$.

Abu Khairan, G. (2011). Delegation of Authority in Civil Society Institutions and Its Role in Promoting Administrative Development in Bethlehem. MA Thesis, Al-Quds University.

Abu Rumman, M. (2011). Factors Affecting Job Satisfaction of the Employees in Travel and Tourism Companies in Amman. International Bulletin of Business Administration, 12, 78-90.

Abu Rumman, M., \& Al-Rahahalh, N. (2016). Training strategy and its impact on the performance of employees. European Journal of Business and Management.

Abu Rumman, M., Al-Zeyadat, A., \& Al-Ateyat, D. (2016). The Impact of Workload and Stress on Employment Alienation: Prospective of Al Isra Hospital Staff (case study). Dirasat: Human and Social Sciences, 43(1), 475-495. https://doi.org/10.12816/0033570

Abu Rumman, M., Jawabreh, O., Alhyasat, K., \& Hamour, H. A. (2013). The Impact of Work Environment on the Average of Job Turnover in Five-Star Hotels in Aqaba City. Business Management and Strategy, 4(2), 111-128. https://doi.org/10.5296/bms.v4i2.4020

Al-Ani, N. (2010). Delegation of authority and Its Impact on Job Performance in the Public Sector Hospitals in Jordan: An Analytical Study. M. A. Thesis, University of Jordan.

Al-Ghazali, H. (2012). The Impact of Transformational Leadership on the Effectiveness of Decision-Making in Jordanian Insurance Companies. M. A. Thesis, Middle East University.

Al-Harbi, A. (2003). Management Control and Its Relationship with Efficient Performance: A Case Study of Customs Officers at King Khalid International Airport. M. A. Thesis, Naif Arab University for Security Sciences, Saudi Arabia.

Al-Harbi, M. (2007). Delegation of Authority amongst Administration Leaders: A Survey of the Ministry of Education. MA Thesis, King Saud University, Saudi Arabia.

Al-Helou, A. (2010). The Effects of Delegation of Authority on Developing Staff's Managerial Skills: A Case Study of Palestinian Universities in Gaza Strip. M. A. Thesis, The Islamic University-Gaza.

Al-Jadba, A. (2007). Measuring the Possibility of Applying the Accountability as a Tool for Monitoring and Performance Evaluation in the Palestinian National Authority Institutions: An Empirical Study. M. A. Thesis, The Islamic University, Gaza.

Al-Othman, M. (2003). Delegation of Authority and Its Impact on the Efficiency of Work Performance. M. A. Thesis, Naif Arab University for Security Sciences.

Al-Twaijri, A. (2006). Delegation of Authority and its Role in the Development of Leadership Skills among staff of Customs Department at King Khaled Airport in Riyadh. M. A. Thesis, Naif Arab University for Security Sciences, Saudi Arabia.

Andrei, I. G., \& Johanna, H. G. (2017). Delegation of Responsibilities and Decision Making Authority in a low trust Countries. Bachelor Thesis in Business Administration. Malardalan Universities 
Boktef, F. (2009). The Impact of the Delegation of Authority on the Effectiveness of Decision-making in Algeria Itar Porcelain Factory in Qalma. M. A. Thesis, Université 20 août 1955 Skikda, Algeria.

Burkan, D. (2011). Effect of Informal Contact on the Decision-Making Process: A Case Study of the Algerian Water Company in Biskrah, A.D.E. Studies in Economics and Administration, X, 214-234.

Darwish, M., \& Al-Shammari, I. (2010). Delegation of Authority: The Best Way to Increase Work Efficiency: A Study of the Views of a Sample of Senior Managers in the Company for the Manufacture of Fertilizers- Central Region / Kufa. Journal of Management and Economics, 96, 51-82.

Diab, A. (2004). Delegation of Authority among UNRWA School Principals in the Northern Governorates of Palestine from Teachers' Perspectives. M. A. Thesis, Al-Najah National University.

El-Zubair, B. T., \& El-Muqati, H. E. N. E. M. (2018). Investigating the Extent of Schools Administrators practice to the Process of Authority Powers (Mandates) to their Deputies from the Standpoint of Deputies in Middle and Secondary Schools in the Province at AL-Taif. International Journal of Educational and Psychological Studies, 3(3), 688-703.

Eshtewi, M. (2013). The Role of E-Governance in the Activation of Effective Communication from the Perspective of Faculty and Administrative Staff in Al Quds Open University-Gaza Branch. Journal of Al-Quds University-Humanities Series, 2(17), 218-248.

Farra, M., \& Shahin, S. (2009). The Reality of Internal Management Control in the Civil Organizations in Gaza Strip. Journal of the Islamic University (Humanities Series), 2, 571-596.

Harb, H. El-D. (2011). The Impact of Personal and Organizational Variables on the Reality of Delegation of Authority among Administration Leaders: An Empirical Study of the Palestinian Ministries In Gaza. M. A. Thesis, the Islamic University-Gaza.

Jaradat, M., AL-Azzam, F., Abu Rumman, M., \& AL-Shra'ah, A. (2012). The Availability of Components Accounting Responsibility in Industrial Companies in Aqaba City. European Scientific Journal, 8(22), 14-27.

Joseph, T S. (2017). $6^{\text {th }}$ International Conference on business and Economic (ICBED). The Business and Management Review, 8(4).

Marginson, D. (2002). Management Control Systems and their Effects on Strategy Formation at Middle Management Levels: Evidence A U.K. Organization. Strategic Management Journal, 23(11), 1019-1031. https://doi.org/10.1002/smj.271

Matar, E. (2008). Organizational Development and Its Impact on the Effectiveness of Management Decisions in Private Institutions in Gaza Strip. M. A. Thesis, the Islamic University-Gaza.

Muhanna, I. (2006). The Relationship between Delegation of Authority and the Effectiveness of Decision-making in Academic Departments from the Viewpoint of Faculty in Palestinian Universities. M. A. Thesis, Al-Najah National University, Palestine.

Naji, B. (2005). Education Administrators' Understanding of Delegation of Authority and the Degree of Practicing it and its Relationship with Efficient Managerial Decision-Making in the Ministry of Education In Jordan. PhD Diss., Amman Arab University for Graduate Studies, Jordan.

Sekaran, U., \& Bougie, R. (2010). Research Methods for Business: A Skill Building Approach (5th ed.). West Sussex: John Wiley \& Sons.

Spanos, Y., Prastacos, G., \& Poulymenakou, A. (2002). The Relationship between Information and Communication and Management. Information and Management, 39(8), 659-675. https://doi.org/10.1016/S0378-7206(01)00141-0

Vikrant, S., \& Rijsdijk, S. A. (2019). Organizational Controls and Performance Outcomes: A Meta-Analytic Assessment and Extension. Journal of Management Studies, 56(1). https://doi.org/10.1111/joms.12342 